\title{
Study on the Influencing Factors of Women's Buying Behavior of Infant Milk Powder
}

\author{
Liang Chen ${ }^{1, \mathrm{a}^{*}}$ and Xiaoyan $\mathrm{Wu}^{1, \mathrm{~b}}$ \\ ${ }^{1}$ School of management, Wuhan University of technology, Wuhan, Hubei, 430070, China \\ acl243660@whut.edu.cn, ${ }^{\text {b } 1055383683<w x y 8801 @ q q . c o m ~}$
}

Keywords: Individual conditions; Personality; Government regulation; Milk safety incidents

\begin{abstract}
This paper, which is from feminist perspective, studies the factors that have influences on young mothers when they choose infant milk powder; meanwhile, it verifies the relationship between some individual conditions (such as income, age, etc.) and their purchasing behavior. In particular, this paper analyzes the correlation between personality and other purchasing factors. In addition, it analyzes the impact of government regulation, past milk safety incidents on the purchase behavior of young mothers. At last, it finds out the factors affecting young mothers whether they will buy domestic milk powder brands or not.
\end{abstract}

\section{Introduction}

According to the National Bureau of statistics, in 2015 the total number of Chinese newborns was 16 million 550 thousand, total sales of infant formula was $¥ 77$ billion 500 million. After the full liberalization of two children, is expected to add up to about 2500000 babies per year, according to estimates of the annual sales of infant milk powder market will increase as high as \$14 billion.

China has a large number of infant milk powder companies and brands, while they have been in disadvantage when competing with foreign counterparts.2015 China imported about 300 thousand tons of milk powder, accounting for $40 \%$ of the total market. However, its sales accounted for $60 \%$ of the total domestic market. Obviously, consumers don't have too much confidence in domestic milk powder.

As the main decision maker, women play an important role in infant milk powder market .Study on the main factors affecting the purchase of infant milk powder will be helpful to understand the consumers' real demand and to provide reference for domestic dairy enterprises. Therefore, this article tries to explore some important factors in the purchase of infant formula from the perspective of women.

\section{Theoretical Analysis and Research Hypothesis}

Theoretical Analysis. There are differences between male and female purchasing behavior. Mody (2012) points out that men and women have different positions in shopping, compared to men, women are less subjective to e-commerce as they need to interact more with the seller [1]. Woodruff(1994)explores the reasons why women hold different attitudes towards online shopping and physical store shopping and finds that emotion, trust and convenience are the main factors[2]. Assae (1992) investigates the perceived risk of buying online, found that, in contrast to men ,ladies perceive a significantly higher likelihood of negative outcomes (e.g., credit card misuse or shipping problems)[3].

Factors affecting women's purchasing behavior. Zhang Qing (2007) analyzes the consumption psychology of Chinese women, pointing out that women's consumption is realistic and imitative, and they are vulnerable to external environmental influences (such as promotion and recommendation), but also focus on product performance and price[4].Jiang Xiaodong (2009,et al. ) study on the influencing factors of brand decision making of Shanghai women in purchasing cosmetics, found that psychological factors, constraints and the use of environmental factors, product factors and corporate behavior factors are the main factors affecting women's decision-making[5].Zhao Jiawei (2012) from the perspective of female consumption psychology, 
suggesting that different marketing strategies should be adopted for different consumer psychology[6].

Factors affecting women's purchase of infant formula. Existing research on milk powder is not uncommon. Some analyze the milk industry of China from a macro point of view, especially the impact of foreign brands on domestic brands; some analyze the competitiveness and base construction of domestic milk powder industry[7,8,9]. Researchers study from the technical point of view, exploring the quality, formula and production technology of milk powder. Most researches are based on the perspective of milk prices and consumers. Liu Hua (2013) analyzed the situation of infant milk consumers in Nanjing City, the study found that consumer awareness, perceived risk, trust and ability to pay and other factors on the purchase behavior have an important influence on the domestic milk, consumers are lack of trust, attaches great importance to the safety and brand[10].Gong Yadi (2015) focuses on the influence of individual conditions, cognitive level, product characteristics and consumption environment on individual purchase behavior in Xuchang.

Research Hypothesis. In this paper, the CDP model is used to analyze the main factors affecting the production of the young ladies from the demand, to collect data, to assess, and to produce the purchasing behavior, and even after the later evaluation and disposal. Recommendation stage includes attention to information and the recommendation from people around, evaluation stage includes income level and consumption capacity, the effect of previous incidents of product and the appraisal of different product characteristics, purchase stage includes choice for brand and channels, evaluation and disposal stage include the appraisal of the performance of the product, whether or not to repeat the purchase.

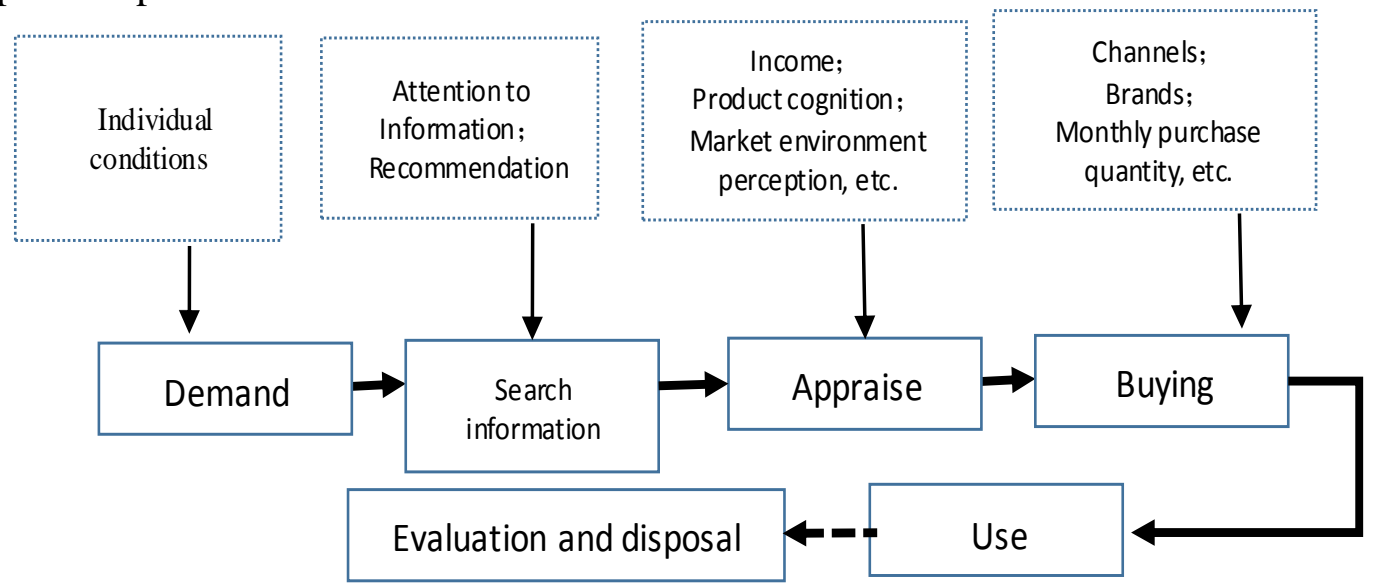

Figure 1. women infant milk powder purchase decision process model

Based on the above theoretical research, this paper puts forward the following assumptions:

1) Age, income and other individual conditions have a significant impact on the purchase behavior

2) There is a correlation between the personality and the satisfaction degree of the purchase environment, the perceived importance of the product characteristics and the purchase decision separately

3) The previous milk safety incidents still have an impact on women's current purchasing behavior

4) There is a correlation between the satisfaction of market regulation environment and women's product cognition and brand purchase.

\section{Data Sources and Research Methods}

A total of 315 questionnaires were collected, and after screening, a total of 283 valid questionnaires were obtained. The questionnaire mainly comes from Wuhan, Zhengzhou, Chongqing, Guangzhou and Beijing 5 cities (a total of 75.25\%), the rest from Shanghai, Jiangsu, Jiangxi and other more than 20 provinces (total of $24.75 \%$ ). It basically covers most parts of China, 
so it has better representation. In this paper, spss20.0 is used to process the data. The main methods include descriptive statistics, cross analysis and correlation analysis.

Descriptive Statistics. The age of the women was 22 to the age of 32, with a total of 250 $(88.34 \%)$.A total of 32 people over the age of $33(11.66 \%)$. As far as the education level is concerned, the majority of college, undergraduate and master are $247(87.27 \%)$. As to family income, the monthly income of $¥ 4500-7500$ are in the majority, a total of 191 people $(67.49 \%) .215$ women think they are outgoing, and the 68 think they are introverted.

The Influence of Individual Condition on Purchasing Behavior.

Table 1 Perceived differences in women of all ages

\begin{tabular}{|c|c|c|c|c|c|c|c|c|}
\hline Pexception & $\begin{array}{c}\text { Attention } \\
\text { to } \\
\text { tofe }\end{array}$ & $\begin{array}{c}\text { Quality } \\
\text { safety } \\
\text { satisfaction }\end{array}$ & $\begin{array}{c}\text { Regulatory } \\
\text { satisfaction }\end{array}$ & $\begin{array}{c}\text { Quality } \\
\text { nutrition } \\
\text { cognition }\end{array}$ & $\begin{array}{c}\text { Recognition } \\
\text { of oomestic } \\
\text { milk } \\
\text { powder }\end{array}$ & $\begin{array}{c}\text { Support for } \\
\text { imported } \\
\text { milk powder }\end{array}$ & $\begin{array}{c}\text { The high } \\
\text { price and } \\
\text { good quality } \\
\text { acceptance }\end{array}$ & $\begin{array}{c}\text { Total } \\
(283)\end{array}$ \\
\hline $20-25$ & $56.99 \%$ & $5.44 \%$ & $7.48 \%$ & $24.49 \%$ & $27.21 \%$ & $49.66 \%$ & $44.22 \%$ & 147 \\
\hline $26-30$ & $86.41 \%$ & $2.91 \%$ & $2.91 \%$ & $22.33 \%$ & $21.36 \%$ & $55.34 \%$ & $31.06 \%$ & 103 \\
\hline $30-35$ & $80.00 \%$ & $5.00 \%$ & $15.00 \%$ & $30.00 \%$ & $30.00 \%$ & $60.00 \%$ & $30.00 \%$ & 20 \\
\hline $36-40$ & $100.00 \%$ & $50.00 \%$ & $50.00 \%$ & $50.00 \%$ & $100.00 \%$ & $50.00 \%$ & $50.00 \%$ & 2 \\
\hline$>40$ & $100.00 \%$ & $18.18 \%$ & $27.27 \%$ & $36.36 \%$ & $45.45 \%$ & $54.54 \%$ & $36.36 \%$ & 11 \\
\hline
\end{tabular}

The results showed that there are significant differences in all aspects of women at different ages. Women under 35 years old are less satisfactory with the quality and regulatory environment of infant formula, they are lack of confidence in domestic milk powder. While women over35 concern more about information related to milk powder, they are much more satisfactory with the quality and regulatory environment of infant formula, their recognition of domestic milk is higher. So hypothesis 1 was verified.

Correlation Analysis. 1) The relationship between personality and other factors influencing purchasing behavior

As an internal factor, personality has an important impact on individual behavior, so this article explores the relationship between personality and other factors affecting the purchase behavior. In order to facilitate the analysis, the female's character is divided into partial introversion and extroversion. The results showed that the previous safety incidents of milk powder has different effects on the different characters, the more outgoing personality, the greater the degree of security incidents (0.211).

There is also a correlation between personality and decision making process (0.527), the outgoing women tend to spend more time collecting relevant information. This can be explained by the relationship between the character and the nutrition of the perception of the importance to judge, they have a significant correlation (0.493), the outgoing women emphasize nutrients, their decision-making process is relatively long. They also pay more attention to the price $(0.527)$, they select to find cost-effective products.

Table 2 Analysis of the relationship between personality and other factors influencing purchasing behavior

\begin{tabular}{|c|c|c|c|c|c|c|c|}
\hline Factor & $\begin{array}{c}\text { The impact of } \\
\text { security } \\
\text { incidents }\end{array}$ & $\begin{array}{c}\text { decision-m } \\
\text { aking } \\
\text { process }\end{array}$ & $\begin{array}{c}\text { Nutrient } \\
\text { composition }\end{array}$ & $\begin{array}{c}\text { Purchasing } \\
\text { convenience }\end{array}$ & Price & $\begin{array}{c}\text { Word of } \\
\text { mouth }\end{array}$ & Brand \\
\hline $\begin{array}{c}\text { Pearson } \\
\text { Correlation }\end{array}$ & $0.211^{* *}$ & $0.527^{* *}$ & $0.493^{* *}$ & $0.293^{* *}$ & $0.527^{* *}$ & -0.028 & 0.043 \\
\hline Sig. (2-tailed) & 0.000 & 0.000 & 0.000 & 0.000 & 0.000 & 0.638 & 0.476 \\
\hline \\
$\begin{array}{l}\text { Ps: **. Correlation is significant at the } 0.01 \text { level (2-tailed).*. Correlation is significant at the } 0.05 \\
\text { level (2-tailed). }\end{array}$
\end{tabular}

2)The relationship between income and other purchasing behavior .The results show that there is a negative correlation between income and some factors influencing purchase behavior. There is a 
negative correlation between the income level and the degree of attention to the relevant information (-0.149). The higher the income, the lower attention to the quality of milk, and the origin, quality and safety signs, manufacturers, production date and shelf life .This can be confirmed from the correlation between income and the common psychological recognition that " high price means high quality" $(0.160)$, the two showed a positive correlation.

There is a positive correlation between income level and domestic milk past security incidents (0.211), the higher the income level, the higher the safety requirements of milk powder, more inclined to choose the infant milk powder of high brand awareness and foreign origin. This can be seen from the correlation between revenue and brand and origin ( 0.160 and 0.124 , respectively). So they do not agree that there is no difference between domestic milk powder and foreign milk powder in terms of quality, nutrition(-0.111). High income women tend to choose foreign brands , and they are more dependent on online channels, overseas purchasing, etc..

Table 3 Analysis of the relationship between income and other purchasing behavior

\begin{tabular}{|c|c|c|c|c|c|c|c|c|c|c|c|}
\hline Factors & \begin{tabular}{|c|} 
Inform \\
ation \\
concer \\
$n$ \\
degree
\end{tabular} & $\begin{array}{l}\text { Quality } \\
\text { safety } \\
\text { satisfact } \\
\text { ion }\end{array}$ & $\begin{array}{l}\text { Choice } \\
\text { tendenc } \\
\text { y of } \\
\text { domesti } \\
\text { c milk } \\
\text { powder }\end{array}$ & $\begin{array}{c}\text { Nutrition } \\
\text { and quality } \\
\text { perception } \\
\text { of milk } \\
\text { powder }\end{array}$ & $\begin{array}{c}\text { Cognitio } \\
n \text { of milk } \\
\text { powder } \\
\text { price }\end{array}$ & \begin{tabular}{|c} 
Attitude \\
towards \\
imported \\
milk \\
powder
\end{tabular} & $\begin{array}{l}\text { Off-line } \\
\text { is more } \\
\text { reliable } \\
\text { than } \\
\text { online }\end{array}$ & $\begin{array}{l}\text { High } \\
\text { price } \\
\text { means } \\
\text { high } \\
\text { quality }\end{array}$ & \begin{tabular}{|c|} 
The \\
impact \\
of \\
security \\
incident \\
s
\end{tabular} & Brand & Origin \\
\hline $\begin{array}{c}\text { Pearson } \\
\text { Correlation }\end{array}$ & $-0.149^{*}$ & $0.166^{* *}$ & $-0.201^{* *}$ & $-0.111^{* *}$ & $0.217^{* *}$ & $-0.225^{* *}$ & $-0.239^{* *}$ & $0.160^{* *}$ & $0.211^{* *}$ & $0.160^{* *}$ & $0.124^{*}$ \\
\hline Sig. (2-tailed) & 0.012 & 0.005 & 0.001 & 0.043 & 0.000 & 0.000 & 0.000 & 0.007 & 0.000 & 0.007 & 0.37 \\
\hline
\end{tabular}

3) Relationship between the impact of security incidents and other purchasing behavior. There is a significant correlation between security incidents and many factors affecting the purchasing behavior. Affected by the degree of security incidents and women satisfaction, the quality and safety of milk to the milk industry, government supervision satisfaction has a negative correlation $(-0.186$ and -0.156$)$, which indicates that women are not satisfied with the quality and safety and supervision of milk.

As a result of the impact of milk safety incidents in the past, women pay more attention to milk powder directly related to information, such as quality, safety, origin, production date and nutrition, etc. (table 4). Because of the existence of information asymmetry, women can not determine whether the milk powder is reliable, they will rely on intuition as a basis for judgment, so the price and brand have become a standard of course.

From the analysis results, the degree of the impact of the previous security incidents and the brand importance $(0.211)$, the price is high, the quality is good, there is a positive correlation (0.211).

At the same time, women are skeptical of the saying that there is no significant differences between domestic and foreign milk powder in terms of nutritional quality (-0.194), the tendency to choose domestic milk purchase also decreases with the deepening of the influence (-0.194), but they do not show a very supportive attitude to imported milk powder(-0.271).It can be seen that the safety of domestic milk powder is one of the most important factors affecting the purchase of infant milk powder. The results of this section show that hypothesis three is supported.

4) The relationship between regulatory satisfaction and other factors influencing purchasing behavior. The degree of satisfaction is a kind of psychological feeling that the government should play a supervisory role in the scope of the government's service. It will affect people's trust in government and industry.

The results shows that there is a high positive correlation between regulatory satisfaction and quality safety satisfaction (0.574), but there is a negative correlation between regulatory satisfaction and the impact of previous milk safety incidents (-0.186). That is to say, the more women are satisfied with government regulation, the more they will be satisfied with the quality of milk powder. 
The less they are affected by milk powder incidents, the more satisfied they are with government regulation.

Table 4 The relationship between the impact of security incidents and other purchasing behavior

\begin{tabular}{|c|c|c|c|c|c|c|c|c|c|c|c|c|c|}
\hline Factors & $\begin{array}{l}\text { Inform } \\
\text { ation } \\
\text { concer } \\
n \\
\text { degree }\end{array}$ & $\begin{array}{l}\text { Quality } \\
\text { safety } \\
\text { satisfac } \\
\text { tion }\end{array}$ & $\begin{array}{l}\text { Regulat } \\
\text { ory } \\
\text { satisfac } \\
\text { tion }\end{array}$ & $\left|\begin{array}{c}\text { Attitud } \\
\mathrm{e} \\
\text { towards } \\
\text { importe } \\
\text { d milk } \\
\text { powder }\end{array}\right|$ & $\begin{array}{c}\text { Nutritio } \\
\mathrm{n} \text { and } \\
\text { quality } \\
\text { percepti } \\
\text { on of } \\
\text { milk } \\
\text { powder }\end{array}$ & $\begin{array}{c}\text { High } \\
\text { prices } \\
\text { are } \\
\text { good } \\
\text { quality }\end{array}$ & $\begin{array}{l}\text { Choice } \\
\text { tendenc } \\
\text { y of } \\
\text { domesti } \\
\text { c milk } \\
\text { powder }\end{array}$ & Brand & Price & $\begin{array}{c}\text { Countr } \\
y \text { of } \\
\text { origin }\end{array}$ & $\begin{array}{c}\text { Produc } \\
t \\
\text { quality }\end{array}$ & $\begin{array}{c}\text { Date of } \\
\text { manufa } \\
\text { cture }\end{array}$ & $\begin{array}{c}\text { Nutrie } \\
\text { nt } \\
\text { compo } \\
\text { sition }\end{array}$ \\
\hline $\begin{array}{c}\text { Pearson } \\
\text { Correlation }\end{array}$ & $0.254^{* *}$ & $-0.156^{*}$ & $-0.186^{*}$ & $-0.271^{*}$ & $-0.194^{*}$ & $0.211^{* *}$ & $-0.194^{*}$ & $0.211^{* *}$ & $0.124^{*}$ & $0.231^{* * *}$ & $0.118^{*}$ & $0.168^{* *}$ & $0.152^{*}$ \\
\hline $\begin{array}{c}\text { Sig. } \\
\text { (2-tailed) }\end{array}$ & 0.000 & 0.009 & 0.001 & 0.000 & 0.001 & 0.000 & 0.001 & 0.000 & 0.038 & 0.000 & 0.048 & 0.005 & 0.010 \\
\hline
\end{tabular}

There is a positive correlation between the degree of satisfaction and the quality perception of domestic / foreign milk powder and the tendency of domestic milk powder ( 0.156 and 0.212 , respectively). When women are more satisfied with the regulatory environment for milk powder, they will be more eager to believe the saying that the quality difference between domestic milk powder and milk powder nutrition is not large.

In addition, there is no significant correlation between brand satisfaction and brand satisfaction, but it has a very significant difference with the word of mouth, the date of production and the nutritional components (table 5).This shows that, in the case of high satisfaction supervision, women will weaken the brand value, and pay more attention to the surrounding people's recommendation, the freshness and nutrition of milk powder. At the same time, they will also choose a more convenient way to buy (0.212). So, hypothesis four is supported.

Table 5 The relationship between regulatory satisfaction and other factors influencing purchasing behavior

\begin{tabular}{|c|c|c|c|c|c|c|c|c|}
\hline Factor & $\begin{array}{c}\text { Nutrition and } \\
\text { quality } \\
\text { perception of } \\
\text { milk powder }\end{array}$ & $\begin{array}{c}\text { Quality } \\
\text { safety } \\
\text { satisfacti } \\
\text { on }\end{array}$ & $\begin{array}{c}\text { Choice } \\
\text { tendency } \\
\text { of } \\
\text { domestic } \\
\text { milk } \\
\text { powder }\end{array}$ & $\begin{array}{c}\text { Purchasing } \\
\text { convenienc } \\
\text { e }\end{array}$ & $\begin{array}{c}\text { The } \\
\text { impact } \\
\text { of } \\
\text { security } \\
\text { incidents }\end{array}$ & $\begin{array}{c}\text { Word of } \\
\text { mouth }\end{array}$ & $\begin{array}{c}\text { Date of } \\
\text { manufact } \\
\text { ure }\end{array}$ & $\begin{array}{c}\text { Nutrient } \\
\text { compositi } \\
\text { on }\end{array}$ \\
\hline $\begin{array}{c}\text { Pearson } \\
\text { Correlation }\end{array}$ & $0.156^{* *}$ & $0.574^{* *}$ & $0.212^{* *}$ & $0.212^{* *}$ & $-0.186^{* *}$ & $0.757^{* *}$ & $0.796^{* *}$ & $0.839^{* *}$ \\
\hline Sig. (2-tailed) & 0.008 & 0.000 & 0.000 & 0.000 & 0.002 & 0.000 & 0.000 & 0.000 \\
\hline
\end{tabular}

\section{The Main Research Conclusions and Relevant Enlightenment}

Main Conclusions. (1) The personality difference will have an impact on women's purchase behavior, which is reflected in the extent of the impact of previous security incidents, the degree of attention to some of the product attributes and the purchase decision-making process.(2)Household income has an important influence on women's whole purchasing process, income not only affects their perception of the safety of milk powder incident, also directly affects the purchase channels as well as the importance of perceived product attributes.(3)The impact of the previous milk powder safety incidents is far from being eliminated, still affecting the satisfaction of women on the regulatory environment and industry, the choice of domestic milk powder and the perception of product attributes.(4)The degree of satisfaction will influence the purchasing behavior of women, such as the choice of channels, the way of purchase, and so on. 
Relevant Enlightenment. (1) Reconstruction of domestic milk consumption confidence. Sanlu milk powder incident in 2008, Synutra precocious event in 2010, Fonterra Botox event in 2013, including a number of infant formula issues exposed in 2016 3.15, have an impact on women's trust for infant milk ,especially the domestic milk powder. Domestic milk powder was of poor quality, accident prone pronoun, but in recent years with the strengthening of national supervision, the quality of domestic milk powder has little difference with foreign milk powder. However, according to the survey, women still has a lot of cognitive errors when it comes to the domestic milk powder, reconstruction of domestic milk consumption confidence also requires the government and domestic milk prices to pay a lot of effort.

(2)Establish the whole process of quality supervision system. The United States has more than 10 well organized divisions to be responsible for food safety management, food safety related laws are as many as 35 [12].Britain has long established a retrospective recall system, set up a unified national database, and realized a real-time tracking of food. New Zealand set up the "three in one" of the Ministry of industry, to be responsible for the supervision of dairy products [13].The United States, the European Union and Australia have clear and strict technical standard milk powder, the United States uses PMO to clear all aspects of technology standards, review procedures and punishment standards, HACCP to monitor the whole process of each link by the European Union and Australia, and Australia also use FSP to control the risk [14].

Compared with the above-mentioned countries and regions, the supervision of dairy products in China is far from enough. In 2013 before the introduction of the ban, and commissioned by the new OEM infant formula of the announcement, and the relevant provisions of the supervision and inspection of the milk prices. In October 1, 2016 the formal implementation of the "management approach" of infant formula milk powder formula product registration, regulation of the industry access threshold, formula and brand of chaos. In the regulatory system, China has a long way to go.

(3)Explore the marketing promotion and channel construction based on personality differences. Character is not easy to detect, but it has a profound impact on people's daily preferences and buying behavior. Therefore, for dairy companies and businesses, they should develop different strategies in marketing and promotion for different character of women. Women who are introverted tend to continue their original spending habits, be cautious and more practical, while extroverts prefer to try and focus on purchasing convenience. First, companies should further understand the characteristics of the customers and make the segmentation. Secondly, they should consider how to effectively maintain the brand loyalty of women with different personalities. For example, to attract the introverted type of female, they can use combined "sales of milk and other baby products ", launch specifically for long-term customer promotions; as for the extrovert type of female ,companies should try to reduce their brand switching and try to meet the convenience and other needs.

In the Internet plus era, milk powder enterprises (business) have more options in developing channels, online channels at the same time, it should be reasonable to evaluate and pay attention to the channel line. For women of different personalities, dairy companies should explore how to improve satisfaction through channel innovation and brand loyalty.

\section{Conflict of Interest}

The author confirms that this article content has no conflict of interest.

\section{References}

[1] Barry Mody Bapathe. Gender Difference Of Shopping Behavior In E- Commerce[D].Harbin Institute of Technology, June 2012.

[2] RB Woodruff, A Dutka. AMA Handbook for customer satisfaction[J]. Journal of Marketing Research, 1994, 31(3).

[3] H Assael. Consumer behavior and marketing action[M].Kent Pub. Co, 1992, 20(1):108-115. 
[4] Zhang Qing. On female consumer psychology and consumption guidance [J]. Lanzhou: "new academic", 2007 (1): 87-89.

[5] Jiang Xiaodong, Gao Weihe, [5]. The influencing factors of consumer brand decision making: An Empirical Analysis Based on Chinese women's cosmetics [J]. "East China economic management", 2009, 23 (10): 115-120.

[6] Zhao Jiawei. On modern women's consumption psychology and enterprise marketing [J]. "Heilongjiang science and technology information", 2012 (2): 207-207.

[7] Feng Qi. the market structure of Chinese infant milk powder industry [J]. "dairy and human", 2008 (4): 9-11.

[8] Gao Yang. Analysis and research status of China infant formula industry -- Based on the analysis of $[\mathrm{J}]$. marketing "modern food safety perspective: Academy edition", 2013 (4): 182-182.

[9] The national high quality current situation and Countermeasures of "[D]." Chinese milk industry, Jilin University, 2012

[10] Liu Hua, Chen Yan. Analysis of the influencing factors of consumer behavior of infant milk powder based on the survey data of 167 consumers in Nanjing [J]. Journal of Hunan Agricultural University (SOCIAL SCIENCE EDITION), 2013 (1): 1

[11] Gong Yadi, Ma x x. Influencing factors of purchasing behavior of infant milk powder in Xuchang [J]. Zhejiang Agricultural Sciences, 2015.56 (3): 383-388.

[12] Yu Guodong, Wang Hongying. The revelation of food safety supervision system in Europe and America on the quality and safety supervision of agricultural products [J]. Jilin agriculture, 2009 (1): 18-19.

[13]Zhu Yuwei. New Zealand dairy product quality and safety supervision system and related standards and regulations [J]. "China dairy industry", 2014, 42 (10): 28-31

[14] Sang Lili, Hua Xin. Supervision and control system of dairy products quality and safety in developed countries [J]. "Food research and development", 2014 (18): 115-118. 